\title{
DAYA DUKUNG LAHAN TAMBAK BUDIDAYA IKAN KERAPU (Ephinepelus spp) DI KECAMATAN BRONDONG KABUPATEN LAMONGAN
}

\author{
Agung Pamuji Rahayu* \\ *Fakultas Perikanan Universitas Islam Lamongan \\ Jl. Veteran no. 53A Lamongan Phone/Fax.0322_324706
}

\begin{abstract}
ABSTRAK
Kegiatan budidaya ikan di wilayah pesisir Kabupaten Lamongan salah satunya adalah budidaya ikan kerapu (Epinephelus spp) ditambak. Budidaya ikan kerapu sebagian besar menggunakan teknologi sederhana dan masih mengalami kendala mulai kasus penyakit, keterbatasan benih unggul, keterbatasan pakan ikan rucah sampai penurunan daya dukung lahan. Upaya memaksimalkan potensi budidaya ikan kerapu harus dilakukan secara rasional dan berkelanjutan. Tujuan penelitian adalah mengetahui profil kegiatan budidaya ikan kerapu dan daya dukung lahan budidaya ikan kerapu ditambak di Kecamatan Brondong Kabupaten Lamongan. Metode yang digunakan adalah metode kuantitatif dan metode pembobotan. Hasil analisis kuantitatif menunjukkan bahwa hasil produksi ikan kerapu terbesar yaitu pada tahun 2014 sejumlah 306,6 Ton sedangkan untuk hasil produksi terkecil yaitu pada tahun 2010 dan 2011 yaitu sebesar 133.06 Ton. Peningkatan prosentase terbesar terjadi dari tahun 2011 ke tahun 2012 dengan prosentase sebesar 88.9\%, hal ini dipengaruhi oleh peningkatan teknologi budidaya serta pemilihan jenis komoditas ikan kerapu. Analisis daya dukung lahan menunjukkan bahwa tambak ikan kerapu di Desa Labuhan Kecamatan Brondong termasuk dalam kategori kriteria daya dukung lahan sedang sampai tinggi dengan faktor pembatas daya dukung lahan tambak antara lain nilai $\mathrm{pH}$ air yang tinggi dengan kisaran 9,8 $\pm 8,2$; Amonia

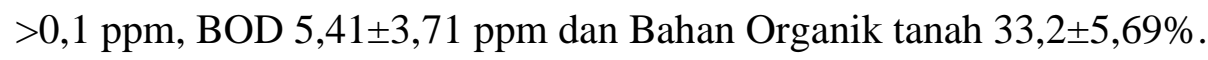

Keyword : Ikan kerapu, profil budidaya, daya dukung lahan

\section{PENDAHULUAN}

Kabupaten Lamongan memiliki luas wilayah kurang lebih $1.812,80 \mathrm{Km}^{2}$ setara 181.280 Ha atau $\pm 3.78 \%$ dari luas wilayah Propinsi Jawa Timur dengan panjang garis pantai sepanjang $47 \mathrm{Km}$. Kabupaten Lamongan merupakan salah satu wilayah yang sangat strategis termasuk sentra produksi perikanan budidaya dan tangkap di Provinsi Jawa Timur Luas lahan budidaya ikan di Kabupaten Lamongan pada tahun 2011 sebesar 25.313 Ha. Khusus untuk pengembangan perikanan tambak (perairan air payau) dengan luas kurang lebih 1.745,4 ha (DPK, 2014). Kawasan tambak tersebar di wilayah pesisir Kabupaten Lamongan yang terdiri dari 2 (dua) Kecamatan yaitu Kecamatan Paciran dan Kecamatan Brondong. Salah satu kegiatan budidaya ikan di Kecamatan Brondong adalah budidaya ikan kerapu ditambak. Jenis ikan kerapu yang dikembangkan antara lain Kerapu Cantik yaitu kerapu jenis hibrid persilangan antara Kerapu Macan (Epinephelus fuscoguttatus) betina dengan Kerapu Batik (Epinephelus microdon); Kerapu Cantang yaitu kerapu jenis hibrid persilangan antara ikan Kerapu 
Macan betina dan Kerapu Kertang (Epinephelus lanceolatus) jantan (Ismi dan Asih, 2011); dan Kerapu Lumpur (Epinephelus coioides).

Budidaya ikan kerapu sebagian besar menggunakan teknologi sederhana dan masih mengalami kendala mulai kasus penyakit, keterbatasan benih unggul, keterbatasan pakan ikan rucah sampai penurunan daya dukung lahan. Upaya memaksimalkan potensi budidaya ikan kerapu harus dilakukan secara rasional dan berkelanjutan. Salah satu upaya untuk memaksimalkan pengembangan budidaya ikan kerapu di Kabupaten Lamongan adalah dengan analisa daya dukung lahan tambak.

\section{METODE PENELITIAN}

Penelitian dilakukan bulan Desember 2016 sampai dengan Januari 2017 dikawasan budidaya ikan kerapu di Desa Labuhan Kecamatan Brondong Kabupaten Lamongan. Analisis kualitas air dilakukan di Laboratorium Lingkungan dan Kesehatan Ikan Keliling Dinas Perikanan Kabupaten Lamongan. Analisis kualitas tanah dilakukan di Laboratorium Fisika dan Kimia Tanah, Fakultas Pertanian, Universitas Brawijaya Malang dan Balai Penelitian Tanaman Aneka Kacang dan Umbi (Balitkabi) Kabupaten Malang.

Alat yang digunakan dalam penelitian daya dukung lahan tambak budidaya ikan kerapu di Kecamatan Brondong, Kabupaten Lamongan adalah alat pengukuran kualitas air (DO meter; $\mathrm{pH}$ pen; refraktometer; sechi disk; dan spektrofotometer); kualitas tanah (soil tester) dan kuisioner. Bahan yang digunakan adalah data primer yang diperoleh dari hasil wawancara dan hasil uji laboratorium/uji lapangan (kualitas air dan tanah) dan data sekunder hasil telaah pustaka serta penelusuran data pada instansi-instansi terkait.

Penelitian ini dilakukan melalui tahapan yang sistematis, logis dan terstruktur, yang terdiri dari 2 tahapan, yaitu

1. Analisa profil budidaya ikan kerapu

2. Analisis daya dukung lahan tambak ikan kerapu

Analisis profil budidaya ikan kerapu dan potensi wilayah di wilayah Kecamatan Brondong melalui analisa dari data sekunder dan data primer. Pada data primer dikumpulkan dengan menggunakan wawancara dan kuisioner kepada responden. Jumlah data sekunder diperoleh dalam kurun waktu 5 tahun terakhir (20102014) dan jenis data sekunder yang dikumpulkan berupa : data volume dan nilai produksi serta data perkembangan luas lahan budidaya tambak Kerapu di Kecamatan Brondong selama kurun waktu 5 tahun terakhir (tahun 2010-2014) dan selanjutnya dianalisis secara kuantitatif.

Analisis daya dukung lahan dengan sistem pembobotan ini mengacu pada modifikasi pemikiran Poernomo (1992) yaitu daya dukung lingkungan itu merupakan nilai kualitas lingkungan yang ditimbulkan oleh interaksi dari semua unsur atau komponen dalam satu kesatuan ekosistem. Metode analisis daya dukung lingkungan ini sebenarnya merupakan kuantifikasi dari kelas kesesuaian lahan dengan cara pemberian bobot pada kelas kesesuaian lahan. Nilai pembobotan kualitas/karakteristik lahan berada antara 1 sampai 3. Dimana, lahan yang memiliki kelas kesesuaian tinggi diberikan bobot tertinggi yaitu 3, kelas kesesuian lahan sedang diberikan bobot 2, kelas kesesuaian lahan rendah diberi bobot 1. Dari simulasi data untuk mengetahui daya dukung lingkungan tambak, yaitu didapatkan kisaran nilai : 
1. Nilai 20-39= Kategori daya dukung rendah

2. Nilai 40-79= Kategori daya dukung sedang

3. Nilai $80-100=$ Kategori daya dukung tinggi

\section{HASIL DAN PEMBAHASAN}

\section{Profil Budidaya Ikan Kerapu di} Kecamatan Brondong

Kegiatan budidaya ikan kerapu ditambak di Kecamatan Brondong selama kurun waktu 5 tahun (2010 - 2014) mengalami kenaikan, hal ini selaras dengan meningkatnya penerapan teknologi budidaya melalui penggunaan kincir air sehingga jumlah padat tebar ikan juga meningkat, selain itu juga dipengaruhi oleh pemilihan jenis komoditas ikan kerapu. Pada awal kegiatan budidaya jenis ikan kerapu yang banyak diusahakan adalah jenis ikan kerapu lumpur (E.coioides). Ikan kerapu lumpur dalam perdagangan internasional sangat populer dengan nama Greasy grouper. Ikan ini memiliki bentuk badan yang gepeng memanjang (Murtidjo, 1988). Pengembangan ikan kerapu lumpur ditambak didukung dengan adanya ketersediaan benih ikan lumpur yang berasal dari hasil tangkapan nelayan sekitar dengan berbagai ukuran mulai dari 50-100 gr/ekor. Masa pemeliharaan ikan kerapu lumpur tergolong cukup lama mulai dari 12-14 bulan untuk mencapai ukuran konsumsi (500 gr keatas) dengan harga jual berkisar Rp. 85.000-90.000;/Kg ditingkat petani. Seiring dengan perjalanan kegiatan budidaya ikan kerapu lumpur mulai mengalami kendala antara lain keterbatasan benih ikan seiring bertambahnya jumlah RTP (Rumah Tangga Perikanan) dan keterbatasan daerah pemasaran. Selanjutnya dilakukan upaya diversifikasi jenis ikan kerapu yaitu dengan memperkenalkan varian baru yaitu kerapu Hybrid. Jenis varietas ikan kerapu baru yaitu persilangan kerapu kertang dan kerapu macan yaitu kerapu Cantang (E. fuscoguttatus $q$ x $E$. lanceolatus $\hat{\jmath}$ ). Selain itu juga dilakukan hybridisasi antara ikan kerapu macan dan ikan kerapu batik yaitu kerapu Cantik ( $E$. fuscoguttatus $q \mathrm{x}$ E. microdon $\widehat{\partial})$. Benih hybrid merupakan upaya diversifikasi spesies ikan kerapu dan memiliki prospek guna meningkatkan produksi perikanan dimasa yang akan datang (Sunarma et al., 2007 dalam Ismi, et al., 2013).

Hasil produksi ikan kerapu di Kecamatan Brondong mulai tahun 2010 hingga tahun 2014 dapat dilihat pada Tabel 1 berikut :

Tabel 1.Hasil Produksi Ikan Kerapu Kecamatan Brondong

\begin{tabular}{cccc}
\hline No. & Tahun & $\begin{array}{c}\text { Jumlah } \\
\text { Produksi } \\
\text { (Ton) }\end{array}$ & $\begin{array}{c}\text { Nilai } \\
\text { Produksi (x } \\
\text { Rp.000) }\end{array}$ \\
\hline 1. & 2010 & 133,06 & 11.310 .100 \\
2. & 2011 & 133,06 & $4.333 .655,1$ \\
3. & 2012 & 251,39 & 20.609 .450 \\
4. & 2013 & 301,31 & 24.727 .506 \\
5. & 2014 & 306,60 & 26.061 .255 \\
\hline & Jumlah & $\mathbf{1 . 1 2 5 , 4 2}$ & $\mathbf{8 7 . 0 4 1 . 9 6 6}$ \\
& Total & & \\
\hline & & & \\
\hline
\end{tabular}

Grafik hasil produksi ikan kerapu mulai tahun 2010 hingga 2014, adalah sebagai berikut (Gambar 1) :

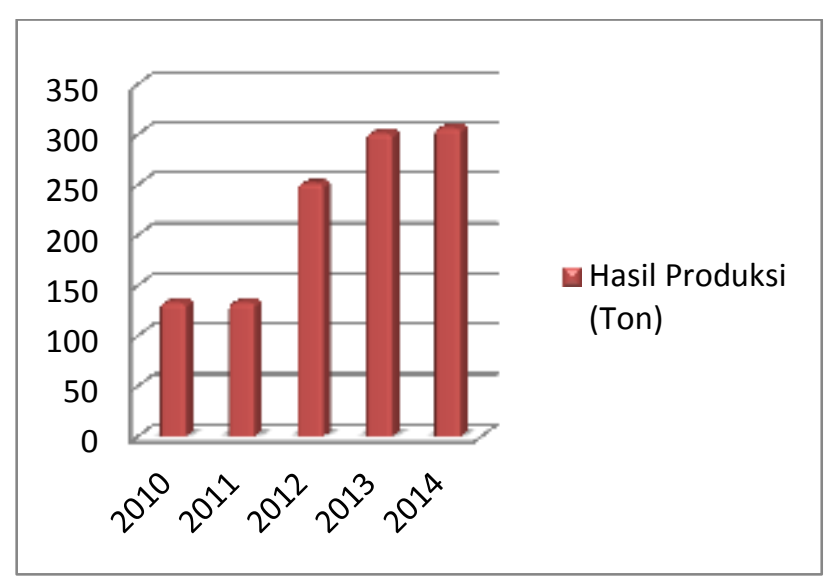


Tabel dan grafik diatas menunjukkan bahwa hasil produksi terbesar yaitu pada tahun 2014 sejumlah 306,6 Ton sedangkan untuk hasil produksi terkecil yaitu pada tahun 2010 dan 2011 yaitu sebesar 133.06 Ton. Jika dilihat dari grafik bahwa dari tahun ketahun jumlah produksi terus mengalami kenaikan dengan prosentase kenaikan sebesar 1,75\% hingga 88,9\%. Peningkatan prosentase terbesar terjadi dari tahun 2011 ke tahun 2012 dengan prosentase sebesar $88.9 \%$. Kenaikan hasil produksi budidaya ikan kerapu di wilayah Kecamatan Brondong Kabupaten Lamongan merupakan hasil dari upaya pemerintah daerah melalui Dinas Perikanan dan Kelautan Kabupaten bekerjasama dengan Stakeholder lainnya dalam upaya pengembangan kegiatan budidaya ikan kerapu. Kegiatan dimulai pada tahun 2009 dengan melakukan MOU (Perjanjian Kerjasama) investor dengan pembudidaya ikan kerapu untuk pengembangan. kawasan jenis ikan kerapu macan antara lain penyediaan benih ikan, teknik budidaya hingga pemasaran hasil budidaya. Seiring berjalannya waktu kegiatan budidaya ikan kerapu macan ditambak banyak mengalami kendala antara lain dari segi pertumbuhan ikan kerapu macan yang relatif cukup lama sehingga secara ekonomis kurang menguntungkan. Menurut Sutarmat et al., (2003) dalam Sutarmat dan Yudha (2013), bahwa pertumbuhan ikan kerapu macan lebih lambat dibandingkan ikan kertang, untuk mencapai ukuran konsumsi dari awal tebar $10 \mathrm{~cm}$ dengan memerlukan masa pemeliharaan 9-12 bulan.

Dinas Perikanan dan Kelautan Kabupaten Lamongan pada Tahun 2012 bekerjasama dengan Balai Besar Penelitian dan Pengembangan Budidaya Laut (BBPPBL) Gondol Bali melakukan diseminasi untuk penyebaran teknologi pembenihan ikan kerapu dibeberapa tempat yang memiliki prospek untuk budidaya agar mempermudah penyediaan benih (Ismi, 2014). Jenis ikan kerapu yang diperkenalkan adalah ikan kerapu hybrid yaitu persilangan kerapu kertang dan kerapu macan yaitu kerapu Cantang (E. fuscoguttatus $q \mathrm{x}$ E. lanceolatus $\widehat{\jmath})$. Ikan kerapu cantang merupakan solusi dari permasalahan umum dalam budidaya ikan kerapu yaitu bagaimana mendapatkan benih ikan kerapu yang tumbuh cepat, konversi pakan rendah, tahan terhadap berbagai kondisi lingkungan, dan penyakit, serta morfologi yang disukai konsumen. Oleh karena itu dalam rangka penyediaan ikan kerapu macan yang berkualitas dan produksi tinggi perlu dilakukan perbaikan keragaan pertumbuhan ikan kerapu macan melalui persilangan antara strain ikan yang potensial untuk budidaya dan dibutuhkan oleh masyarakat.

Dengan munculnya varietas ikan kerapu hybrid, jenis ikan kerapu cantang secara drastis meningkatkan produksi budidaya ikan kerapu ditambak di wilayah Kecamatan Brondong Kabupaten Lamongan. Masyarakat khususnya pembudidaya ikan kerapu secara bertahap beralih komoditas dari ikan kerapu macan ke jenis ikan kerapu cantang karena keunggulan yang dimiliki salah satunya adalah dari segi pertumbuhan yang tergolong cepat dimana dalam kurun waktu pemeliharaan 5-6 bulan dari ukuran 7-8 cm dapat mencapai ukuran konsumsi sebesar 500 gr/ekor. Pertumbuhan bobot rata-rata ikan kerapu hybrid dan kerapu macan selama 6 bulan pemeliharaan masingmasing $868 \pm 58$ gr dan 285 \pm 34 gr (Sutarmat dan Yudha, 2013). Analisis laju pertumbuhan bobot menunjukkan bahwa perkawinan silang memberikan pengaruh sangat nyata terhadap benih hasil 
perkawinan silang antara kerapu kertang jantan dengan ikan kerapu macan betina. Kerapu hybrid hasil perkawinan silang antara ikan kerapu kertang jantan dan ikan kerapu macan betina mempunyai nafsu makan yang tinggi serta dapat memanfaatkan pakan yang lebih baik jika dibandingkan dengan benih kerapu lainnya.

Untuk memicu produksi budidaya ikan kerapu ditambak Dinas Perikanan dan Kelautan Kabupaten Lamongan pada tahun 2012 juga memberikan bantuan berupa pengadaan jaring apung untuk pendederan ikan kerapu (DPK Kabupaten Lamongan, 2012). Hal ini sebagai hasil evaluasi kegiatan diseminasi benih ikan kerapu cantang yang menunjukkan hasil positif terutama dalam rangka penyediaan benih ikan kerapu cantang dalam skala yang lebih besar. Pada tahun 2013 melalui Program GEMERLAP (Gerakan Membangun Ekonomi Rakyat Lamongan Berbasis Pedesaan) memberikan bantuan dalam bentuk barang yang berasal dari dana APBD II, berupa Dana Alokasi Khusus (DAK) serta Dana Bagi Hasil Cukai dan Hasil Tembakau (DBHCHT). Bantuan tersebut dalam bentuk pengadaan benih dan pakan ikan. Program bantuan untuk peningkatan teknologi juga telah diluncurkan dengan pemberian bantuan pengadaan kincir air untuk tambak dan pengembangan budidaya ikan kerapu pada tahun 2013. Selanjutnya untuk meningkatkan produksi pakan maka pada tahun 2014 kelompok pembudidaya ikan kerapu di Kecamatan Brondong diberikan bantuan berupa pengadaan mesin produksi pembuatan pakan ikan. Berdasarkan luasan tambak budidaya ikan kerapu mulai dari tahun 2010 hingga tahun 2014 tidak ada penambahan jumlah luasan yaitu seluas 217,152 Ha, hal ini disebabkan tidak adanya aktualisasi data luasan budidaya ikan kerapu di wilayah Kecamatan Brondong Kabupaten Lamongan sampai dengan tahun 2016 melalui program enumerator tambak di wilayah Kecamatan Brondong.

\section{Daya Dukung Lahan Budidaya Ikan Kerapu ditambak di Kecamatan Brondong}

Hasil penghitungan kelas daya dukung lahan tambak budidaya ikan kerapu di Desa Labuhan Kecamatan Brondong, Kabupaten Lamongan secara garis besar menunjukkan daya dukung lahan tergolong sedang dan tinggi. Adapun faktor pembatas untuk kualitas tanah adalah bahan organik dimana kisaran nilai 33,2 $\pm 5,69 \%$. Kandungan bahan organik tanah tambak. Bahan organik tanah yang masih dapat ditoleransi oleh ikan kerapu adalah dengan kandungan 5-10\% (Supratno dan Kasnadi, 2003). Upaya yang bisa dilakukan untuk mengatasi bahan organik tanah yang tinggi adalah dengan dilakukannya penjemuran dan pembalikan pada tanah dasar tambak pada saat persiapan lahan, sehingga terjadi proses oksidasi. Faktor pembatas kualitas air antara lain $\mathrm{pH}$ air, dimana Kisaran nilai $\mathrm{pH}$ yang diperoleh pada setiap stasiun pengamatan yaitu $8,2 \pm 9,8$. Dari hasil pengukuran kadar amonia pada penelitian disetiap stasiun pengamatan menunjukkan bahwa nilai amonia bekisar antara $0,155 \pm<0,05 \mathrm{ppm}$, hal ini berarti bahwa nilai amonia masih dalam tahap yang bisa ditolerir oleh ikan kerapu ditambak. Menurut Poernomo (1992) bahwa batas toleransi amonia untuk usaha budidaya tambak adalah 0-0,25 ppm sedangkan amonia yang aman untuk budidaya ikan kerapu ditambak adalah kurang dari 0,01 ppm (Supratno dan Kasnadi, 2003). Hasil analisis kualitas air tambak pada stasiun pengamatan menunjukkan bahwa nilai 


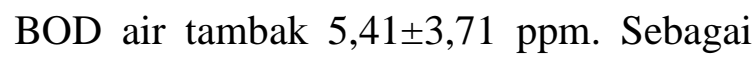
upaya untuk meminimalisasi kandungan BOD adalah dengan dilakukannya sirkulasi air dengan pemanfaatan kincir (aerasi) sebagai penambah oksigen terlarut. Dapat juga dilakukan upaya untuk reklamasi atau pengolahan tanah dasar dan pengeringan yang lebih lama melalui proses oksidasi.

\section{KESIMPULAN DAN SARAN}

Dari hasil penelitian Daya Dukung Lahan Tambak Budidaya Ikan Kerapu di Wilayah Kecamatan Brondong, Kabupatn Lamongan Propinsi Jawa Timur, maka dapat disimpulkan sebagai berikut :

1. Hasil analisis kuantitatif menunjukkan bahwa hasil produksi terbesar yaitu pada tahun 2014 sejumlah 306,6 Ton sedangkan untuk hasil produksi terkecil yaitu pada tahun 2010 dan 2011 yaitu sebesar 133.06 Ton. Peningkatan prosentase terbesar terjadi dari tahun 2011 ke tahun 2012 dengan prosentase sebesar $88.9 \%$, hal ini dipengaruhi oleh peningkatan teknologi budidaya serta pemilihan jenis komoditas ikan kerapu

2. Analisis daya dukung lahan menunjukkan bahwa tambak ikan kerapu di Desa Labuhan Kecamatan Brondong termasuk dalam kategori kriteria daya dukung lahan sedang dan tinggi. Faktor pembatas daya dukung lahan tambak antara lain nilai $\mathrm{pH}$ air yang tinggi dengan kisaran 8,2 $\pm 9,8$; Amonia >0,1 ppm, BOD 3,71 $\pm 5,41$ ppm dan Bahan Organik tanah $5,69 \pm 33,2$

Adapun saran yang dapat diberikan yaitu :

1. Perlu upaya intensifikasi budidaya ikan kerapu ditambak melalui peningkatan teknologi budidaya dari semi intensif ke intensif.

2. Perlu dilakukan solusi alternatif dari permasalahan yang ada maupun beberapa faktor pembatas seperti : $\mathrm{pH}$ air, Amonia, BOD dan Bahan organik tanah pada budidaya ikan kerapu ditambak. Perlu upaya intensifikasi budidaya ikan kerapu ditambak melalui peningkatan teknologi budidaya dari semi intensif ke intensif.

\section{DAFTAR PUSTAKA}

DPK Kabupaten Lamongan. 2012. Laporan Akhir Kegiatan Pengadaan Jaring Apung Pendederan Kerapu Tahun 2012. Lamongan

Dinas Perikanan dan Kelautan Kabupaten Lamongan. 2014. Data Potensi Perikanan Budidaya Kabupaten Lamongan. Laporan Tahunan 2014

Ismi,S dan Y.N.Asih. 2011a. Pengamatan perkembangan benih kerapu hybrid persilangan antara kerapu macan (Epinephelus fuscoguttatus), kertang (Epinephelus lanceolatus). Prosiding Seminar Nasional Kelautan VII. Universitas Hang Tuah, Surabaya 20 April 2011. Hlm : 100-104

Ismi, S., dan Y.N. Asih. 2011b. Perkembangan telur dan tingkah laku larva kerapu hybrid cantang. Prosiding Forum Inovasi Teknologi Akua-kultur. Bali19-21 Juli 2011. Hlm.: 9-12.

Ismi, S, Y.N. Asih dan D.Kusunawati. 2013. Peningkatan produksi dan kualitas benih ikan kerapu melalui program hibridisasi. Jurnal Ilmu dan Teknologi Kelautan Tropis, 5 (2) : 333-347.

Ismi, S. 2014. Aplikasi teknologi pembenihan kerapu untuk mendukung pengembangan budidaya laut. Jurnal Ilmu dan Teknologi Kelautan Tropis. 6 (1) : 109-119 
Poernomo, A. 1992. Pemilihan Lokasi Tambak Udang Berwawasan Lingkungan. Seri Pengembangan Hasil Penelitian No. PHP/KAN/PATEK/004/1992. Badan Penelitian dan Pengembangan Pertanian, Pusat Penelitian dan Pengembangan Perikanan bekerjasama dengan USAID/FRDP, Jakarta. 40 hlm

Supratno. K.P, T dan Kasnadi. 2003. Peluang usaha Budidaya Alternatif dengan Pembesaran Kerapu di Tambak Melalui Sistem Modular. Pelatihan Budidaya Udang Windu Sistem Tertutup bagi Petani Kab. Tegal dan Jepara- Jateng 19 Mei - 8 Juni 2003, di BBPBAP. Jepara. 